\title{
自覚症状と性格との関連についての研究
}

東京慈㭧会医科大学古䦥内科教室

\begin{tabular}{|c|c|c|c|}
\hline 義之， & 桶口 & 正元, & 内田 \\
\hline $\begin{array}{l}\text { 真次, } \\
\text { 直的 }\end{array}$ & 長山 & 秀雄, & 吉田 \\
\hline
\end{tabular}

\section{A STUDY ON THE CORELATION BETWEEN SUBJECTIVE SYMPTOMS AND CHARACTER}

\section{BY}

\author{
Y. Koga, M. Higuchi, M. Uchida, S. Miyajima, \\ H. Nagayama, Y. Yoshida, and S. Kusano. \\ Department of Internal Medicine (Koga Clinic),
}

Tokyo Jikeikai Medical College

\begin{abstract}
梗概 自覚症状乞性格との関連についての問題を解明する一助として, 一つには psycho-somatic,

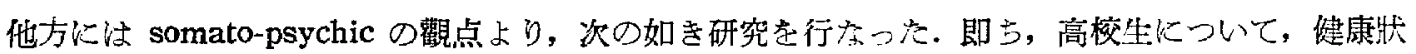

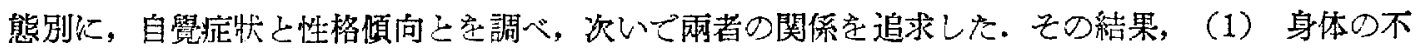

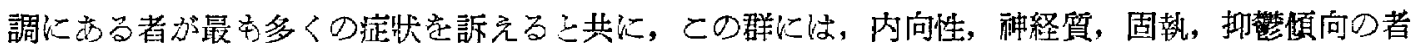
が多かった（2）健康であると自ら考えている者の中にも, 詳しく調查すると種々なる不定の症

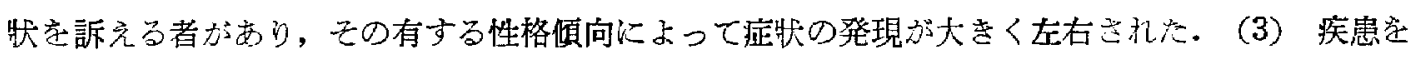
有する者は性格傾向によって, その症狀の発現が左程影響されなかった，以上についてそれぞれ考， 案学試及，性格傾向の把握が，患者の取扱い上に如何に重要で交るかと云う事を改わて認識した。
\end{abstract}

緒 言

物理化学と生物学を基礎として発展した現代医 学が，いかに精密なる機峨器具を駆使しょうと も，人間が心身両面を有する複雑なる生体である ということを閉却するならば，必然，ある時期 に，少な名らぬ疑点に遭遇して当惑せざるを得な いであろう。こっに，疾艎を正しく診断・治療す るに当つては，蝟者を心身雨面加ら眺めて行くこ とが大切であるということが痛感される。これに は，まず，訴えられる症状の正しい吟味と性格傾 向の十分なる把握方必琶であり，次いで両者の相 互関係が追求されなければならない。これには二 つの問題が提起されよう。その一つは, 人間が,あ
る疾患に罹患した場合，それによつていかなる 精神的影響を受けるかという somato-psychic な 問題であり，他の一つは，精神的要因が，ある疾 患の発病, 経過, 予後にいかなる影響をもたらす かという psycho-somatic な問題である.われわ れは，これらの問題の解明の一助として，高校生 を対象に選び, 彼らの健康状熊, 自覚症状,なら びに，性格傾向を調查し，次いで，身体状況別に 後二者の相互関係を追求することを試みて, 興味 ある成績を得たので，こっに報告する。

\section{研究方法}

I . 研究対象

年令15〜18才まで,ツ反応既陽性で通学中の高 


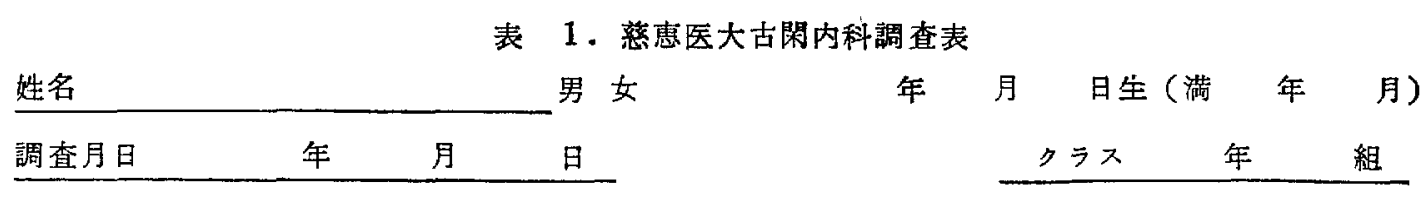

次の質問の該当するところへ○印をつけ必要事項を記入して下さい。

I. 健康状態

（1）現在健康で元気化通学している.

（2）現在病気はないが，何処となく身体の調子がわるい。

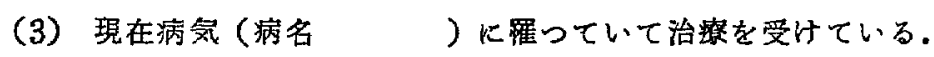

I. 既 往 症

（1）結核性疾患（病名持）

(2) イイローゼ( す時)

(3) 眼の病気(病名持)

（4）その他床についたり, 相当長く病院に通つた様な病気に就いて病名, 罹つた時の年令, 治 るまでの期閒, 治䪰法等.

I. ツベルクリン反庶

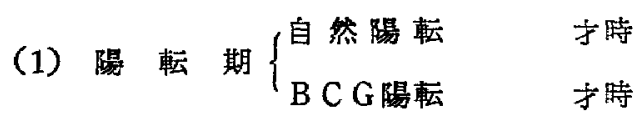

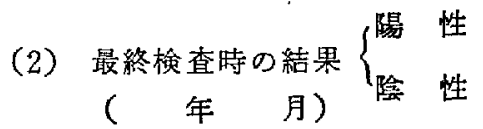

校生 984名（男子 672名，女子 312名）を対象と した。

\section{I. 椧查項目}

(1) 健康状態調查

表 1 の調查表によつて各人の健康状態を調査 し, 全例を 1) A群 (健康者群)，2）B群（不調 者群)，3） C群 (疾患群)に分けた。A群は，現 在健康で元気に通学している（表1，Iの（1） 者，B群は，現在病気はないが，どことなく身体 の調子がわるい(表1，Iの（2））者であり，再群 とも自己制断によつた。C群は, 現在, 病気に加 〉つていて治療を受けている（表1，Iの（3））者 で, 医師の診断によるものである，疾患の内訳は 表 2 の゙とくである.

\section{（2）白覚症状調查}

表 3 の肺結核患者機能病理調查表1)を用いて， 現在の身体の異状を記入せしわて調查した。この 調查表は Pottenger 氏 ${ }^{1)}$ の中毒症候（症状欄左 端 $\left.{ }^{1)}\right)$, 内葴反射症候 (同 $\left.{ }^{2}\right)$ 病巣局所症候 (同 ${ }^{3)}$ ) を示すもので，氏によると，（1）中毒症候は， 結核菌毒素により惹起された葴器障害の症候で，

表 2.C群(疾患群)の病名及び数

\begin{tabular}{|c|c|c|c|c|}
\hline 夷告 & 内向性 & 丙向性 & 外向性 & tᄒ十 \\
\hline トラコーマ & 1 & 13 & 11 & 25 \\
\hline 結膜炎 & 6. & 23 & 8 & 37 \\
\hline 中耳炎 & 1 & 1 & $\theta$ & 2 \\
\hline 到鼻啌炎 & 3 & 1 & 3 & 7 \\
\hline 臭中隔蒙曲症 & 1 & 0 & 0 & 1 \\
\hline 咸 冒 & 0 & 1 & 1 & 2 \\
\hline 南飭炎 & 0 & 0 & 1 & 1 \\
\hline 脚 成 & 0 & 3 & 0 & 3 \\
\hline 高血压痁 & 0 & $t$ & 0 & 1 \\
\hline 喘 息 & 0 & 1 & 0 & 1 \\
\hline 偏䊖痛 & 0 & 1 & 0 & 1 \\
\hline 鼻 炎 & 1 & 1 & 0 & 2 \\
\hline 崤青 & 0 & 0 & 1 & 1 \\
\hline 計 & 13 & 46 & 25 & 84 \\
\hline
\end{tabular}

必ずも結核症に特有なものではないが，生体反 応の表現として診断上重要視すべきものとされ， (2).内臟反射症候は菌毒素が神経を介して間接 的に, その勃果器官に現われる症候群であつて, 結核症の疑徴とも言うへきものであり，また(3) 病巣局所症候は肺結核そのものより起こる症状で 
表 3 . 古閉内科肺結核患者機能病理調查表

\begin{tabular}{|c|c|c|c|c|c|}
\hline 籍 & 号 & 調查年月日 & 年 & 月 & 日 \\
\hline $\begin{array}{l}\text { 氏 } \\
\text { 名 }\end{array}$ & & & & & 女 \\
\hline
\end{tabular}

下記の症状のうちあるものの頭に○印をつけて下さい。

\begin{tabular}{|c|c|c|c|c|}
\hline (1) & $\begin{array}{l}\text { 気分がすぐれない } \\
\text { いらいらする }\end{array}$ & $\begin{array}{l}\text { つかれ易い } \\
\text { 頭が痛い }\end{array}$ & $\begin{array}{l}\text { 物事にあき易い } \\
\text { 気が落ちつかぬ } \\
\end{array}$ & $\begin{array}{l}\text { することが扣つくうだ\}一般感悄障害 } \\
\text { 眠れない }\end{array}$ \\
\hline & $\begin{array}{l}\text { 夢を見る } \\
\text { 熱が上つたり下つたり }\end{array}$ & $\begin{array}{l}\text { 汗が出易い } \\
\text { 胸ぐるしい }\end{array}$ & $\begin{array}{l}\text { ね汗が出る } \\
\text { 動きがする }\end{array}$ & $\begin{array}{l}\text { 熱がある } \\
\text { 息ぎれがする }\end{array}$ \\
\hline & $\begin{array}{l}\text { 胃がはればつたい } \\
\text { 胸がやける } \\
\text { 便通がない }\end{array}$ & $\begin{array}{l}\text { 昍き気がする } \\
\text { げるがが出る } \\
\text { 下痢する }\end{array}$ & $\begin{array}{l}\text { 食欲がない } \\
\text { 胃がいたい } \\
\text { のどがかわく }\end{array}$ & $\begin{array}{l}\text { お腹が空きすぎる } \\
\text { 腹がいたい }\end{array}$ \\
\hline & $\begin{array}{l}\text { 滬が出易い } \\
\text { 毛が抜ける }\end{array}$ & 手屋がだるい & 体重がへる & 手足が冷い \\
\hline (2) & $\begin{array}{l}\text { 声がかれる } \\
\text { 肩がこる }\end{array}$ & $\begin{array}{l}\text { 㬋頭がおかしい } \\
\text { 熋中がいたむ }\end{array}$ & $\begin{array}{l}\text { 咳が出る } \\
\text { 頉が紅い }\end{array}$ & $\begin{array}{l}\text { 胸がいたい } \\
\text { 月経不頎 }\end{array}$ \\
\hline (3) & 風邪をひき易い & 風邪が仲ふなおら奴 & 喀血する & 痰が出る \\
\hline
\end{tabular}

あつて，診断上一つの確徴とみるべきものである と考えられている。自覚症状の調查に本調査表を 選んだのは，各症候が一般的で理解され易いとい うこと〉, 対象が結核発病の危険年令層に該当し, ツ反応が全員既陽性であることなどのためであ ろ.

\section{（3）性格調查}

性格調查には Inventory Test として, 1) 古 閑の向性検查 ${ }^{2} ， 2$ ）淡路氏向性検查 ${ }^{3)} ， 3$ ） Y-G 自己診断法4，4）Taylor 不安テスト5)などを 施行し，綜合的に刵断して内向性傾向のまさつて いるものを内向性，外向性傾向のまさつているも のを外向性とし，とくにかたよつた傾向の見出せ ないものを一広両向性（中間型）とした。なお， 10項目の Y-G 自己診断法より，神経筫，固執， 抑㯊傾向の強いものを選び，それぞれ， $\mathbf{N}$ 群， $\mathbf{P}$ 群およびD群とした。

\section{III. 検查時期}

以上の諸検查はすへて1958年の夏李 7 月に施行 した。

\section{IV. 推計学的刵定法}

得られた成績はすへで推計学的に比較検定 し，その有意差制定の危険率は $5 \%$ 以下とし，10
\%を有意差傾向とした。

\section{研究成績}

1. 健康状態,および，性格傾向について

表 4 に示すごとく， $\mathbf{A}$ 群（健康者群）は 724 名 （うち男性 491，女性 233）で全例の72.5\%を占 め，これを向性别に観ると，内问性 129名（17.8 $\%$ ), 両向性 364名 (47.9\%), 外向性 231名 (33.2 $\%$ ，神経質傾向の強いもの（N群） 142名（19.6 $\%$ ，固坏傾向の強い字の（P群）145名（20.01 \%), 抑管傾向の強い歹の（D群）98各 (13.5\%) であつた。B群 (不調者群) は169名（うち男性

表 4. 向性別に観た各群の例数

\begin{tabular}{|c|c|c|c|}
\hline & $\begin{array}{|cc|}A & \text { 群 } \\
\text { (使 } & \text { 者砽) } \\
\end{array}$ & \begin{tabular}{|cc} 
B 群 \\
(子圽古群)
\end{tabular} & 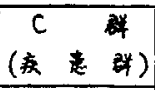 \\
\hline & 例 教 $(\%)$ & 例 数 $(\%)$ & 例 数 $(\%)$ \\
\hline 内向性 & $129(17.8)$ & $44(26.0)$ & $16(17.5)$ \\
\hline 两向性 & $364(47.9)$ & $86(50.8)$ & $47(5 / .6)$ \\
\hline 外向性 & $23 /(33.2)$ & $39(16.5)$ & $28(30.7)$ \\
\hline 合 部 & $724(72.5)$ & $169(17.1)$ & $9 /(9.2)$ \\
\hline 群 & $142(19.6)$ & $66(39.0)$ & $19(20.8)$ \\
\hline 群 & $145(20.0)$ & $65(38.4)$ & $19(20.8)$ \\
\hline D群 & $98(13.5)$ & $63(37.2)$ & $17(18.6)$ \\
\hline
\end{tabular}


122，女性47）で全例の17.1\%を占め，これを向 性別にみると，内向性44名 (26.0\%), 両向性86名 (50.8\%), 外向性39名 (16.5\%), N群66名 (39.0 $\%), \mathrm{P}$ 群65名 (38.4\%), D群63名 (37.2\%) であ つた。C群（疾患群）は91名（うち，男性59，女 性32）で全例の 9.2\%を占め，これを向性別に観 ると内向性16名 (17.5\%), 両向性47名 (51.6\%), 外向性28名 (30.7\%), N群19名 (20.8\%), P群は 同じく19名 (20.8\%), D群17名 (18.6\%) であつ た。以上の成績を小括すると，A群は他の 2 群に 比し大多数を占めていた。Ｂ群の内问性，神経質 傾向, 固執傾向および抑禁傾向のものは, 他の 2 群 (A・C群) のそれに比し，それぞれ有意 (内 向性 $\chi^{2}=5.991$, 神経質傾向 $\chi^{2}=13.815$, 固執傾 向 $\chi^{2}=13.815$, 抑禁傾向 $\left.\chi^{2}=13.815\right)$ の多数を 占め, また，外向性のものが他の 2 群のそれに比 し少数の傾向 $\left(\chi^{2}=5.074\right)$ を示した。換言すれ ば，B群が，他の 2 群に比し，その性格傾向にお いて，内向性，神経質，固執抑禁傾向の強いもの の多いことがわかつた。

\section{2. $\mathbf{A} ・ \mathrm{~B} ・ \mathrm{C}$ 群別に筧た症候の現わ方}

表 5 （1）(2)に示すごとく, 各群とも, 症候の 現われ方は, 機能病理調查表の（1）群（中毒症 候）の発現頻度が最も多く,中でも，上 2 段の一般 感情障害が全体の $1 / 3$ 強を占め, 次いで（2)群（葴 器反射徴候)（3）群（病巣局所徴候）の順に減 少している，それそれの発現頻度の大なるもの10 項目を挙げると表 6 のごとくである。これを各群 別にみるとB群において, 症候の発現頻度が有意 差ならびに傾向をもつて最も多い項目の数が他の 2 群に比し, 有意 $\left(\chi^{2}=13.815\right)$ の多数を占めて いることがわかつた。換言すれば，B群（不調者 群）が最も多く症候を訴えていることになる（B 群25項目, C群 5 項目, A群 0).

3. 向性別による各群の症候の現われ方

向性別に A・B・C各群の症候の現われ方をみ ると，まずA群では表 7 (1)（2）, 内向性群に有 意差ならびに傾向をもつて症候の発現頻度の大な
表 5. 各群（健康者群・不調者群・疾患群） 別にみた症候の現れ方

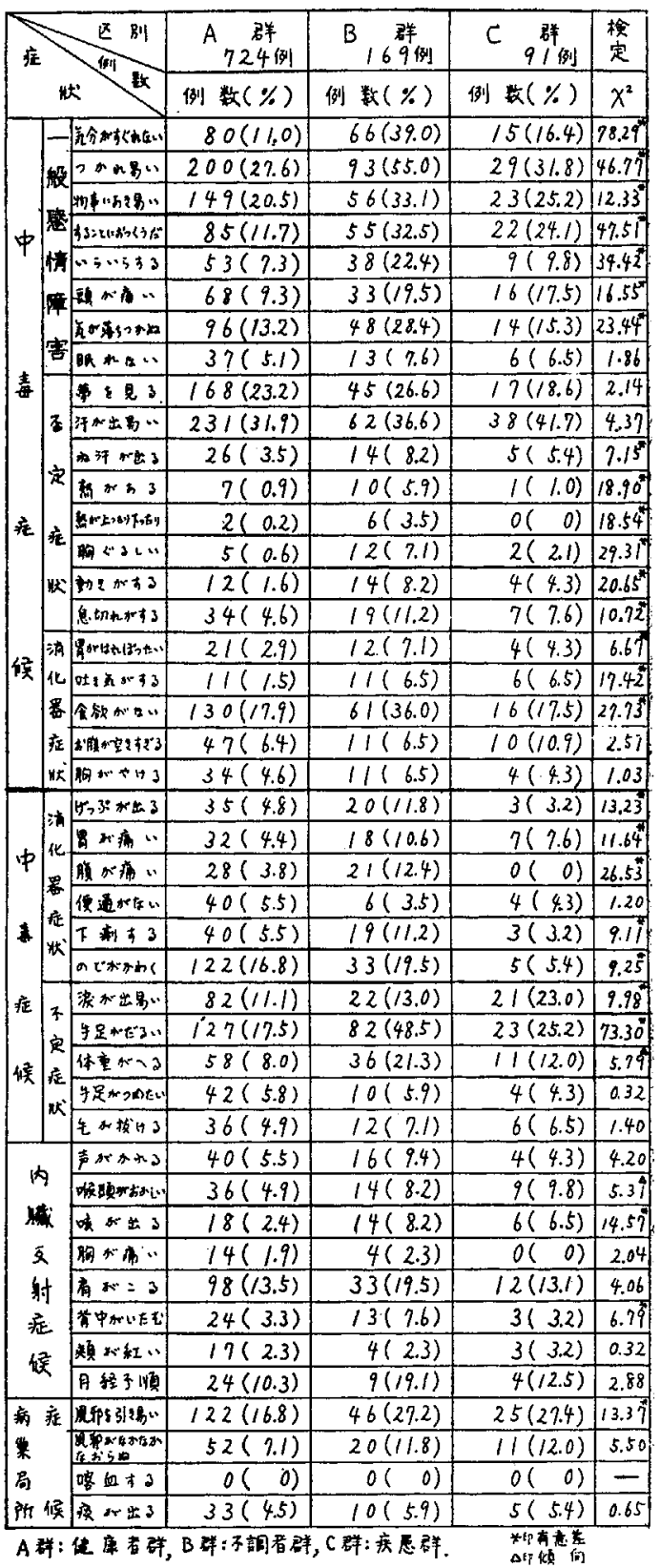

る項目が最も多く (18項目), 両向性群, 外向性群 にはそれでれ1項目をみるに過ぎなく，内向性群 において症候の発現頻度の大なる項目は他の 2 群 に比し有意差 $\left(\chi^{2}=13.815\right)$ を以て多数を占めて いることがわかつた。換言すれば，A群では，内 向性のものが最も多く症候を訴えていることにな る. 次に B群では表 8 （1）（2），向性別による 
表 6. 発現頻度の多い10項目

\begin{tabular}{|c|c|c|c|c|c|c|c|}
\hline \multirow{2}{*}{\multicolumn{2}{|c|}{$\sum_{1}^{\text {E }}$}} & \multicolumn{2}{|c|}{ A 群 } & \multicolumn{2}{|c|}{ B 群 } & \multicolumn{2}{|c|}{ C 群 } \\
\hline & & 汗が出易い & 231 & 汗が蛙易い & 93 & 汗为象” & 38 \\
\hline & 2 & つが易い & 200 & 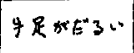 & 82 & 二か九曼・ & 29 \\
\hline \multirow[b]{2}{*}{ 候 } & 3 & 苦 173 & 168 & 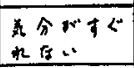 & 66 & 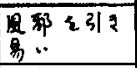 & 25 \\
\hline & 4 & $\begin{array}{l}\text { 物事口斿 } \\
89\end{array}$ & 149 & $\Rightarrow$ か心男 & 62 & 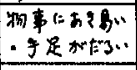 & 23 \\
\hline \multirow{2}{*}{ 縉 } & 5 & 食欲加在心 & 130 & 金合がはい & 61 & $\begin{array}{l}\hbar 3=r= \\
\hbar つ<j="\end{array}$ & 22 \\
\hline & 6 & 是がE゙るい & 127 & $\begin{array}{l}\text { 物事に5 } \\
\text { 员 }\end{array}$ & 56 & 港が出男” & 21 \\
\hline \multirow{2}{*}{ 桝 } & 7 & 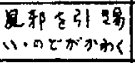 & 122 & 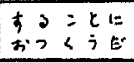 & 55 & 要 543 & 17 \\
\hline & 8 & 房 & 98 & 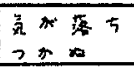 & 4.8 & 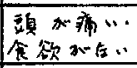 & 16 \\
\hline \multirow{2}{*}{ 数 } & 9 & 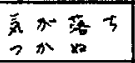 & 96 & 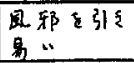 & 46 & $\begin{array}{l}\text { 美合い゙すぐ } \\
\text { れ }\end{array}$ & 15 \\
\hline & 10 & 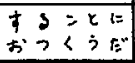 & 85 & 费々 & 45 & 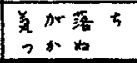 & 14 \\
\hline
\end{tabular}

症候の現われ方にはほとんど差がなく，有意差， ならびに，傾问をもつて症候の発現頻度の大なる 項目は内向性群に 2 項目, 外向性群に同じく 2 項 目を見るに過ぎい，換言すれば，B群では，そ の症候の発現が，内・両・外 3 向性間にはほとん ど差がみとめられないということがわかつた。ま た，群では（表 9（1）(2)）, 有意差ならびに傾 向をもつて症候の発現頻度の大なる項目は内向性 群に 5 項目, 両向性群に 2 項目，外向性群に 1 項 目で， 3 群間において，発現頻度の大なる項目に 有意差はみとめられなかつた。換言すれば，C群 ではB群と同じく症候の発現が，内・両・外 3 向 性間にほとんど差をみとめないということがわか つた.

次に，神経質傾向，固執傾向，抑禁傾向の強い ものが示す症候の発現頻度を，それそれの対象に 此較すると，まずA群においては（表10 (1)(2)） 有意差ならびに傾向をもつて症候の発現頻度の 大なる項目はN群23， P群22， D群25で，それ それれ対象（非N群 0 , 非P群 0 , 非D群 0) に 此し有意 $\left(\mathrm{N} . \chi^{2}=6.635, \mathrm{P} \cdot \chi^{2}=10.827, \mathrm{D} . \chi^{2}=\right.$ 10.827）の多数を占めた。次にB群では（表11 (1)（2)，同じく有意差ならびに傾向をもつて症 候の発現頻度の大なる項目はN 群 $9, \mathrm{P}$ 群 $12, \mathrm{D}$ 群16で，それぞれの対象（非N群 0, 非P群 0 , 非D群 3 ) に比し, 有意 $\left(\mathrm{N} . \chi^{2}=6.635, \mathrm{P} \cdot \chi^{2}=\right.$
表 7. 向性别にみた症候の現れ方 $\mathrm{A}$ 群（健康者群）

\begin{tabular}{|c|c|c|c|c|c|}
\hline \multirow{2}{*}{\multicolumn{2}{|c|}{ 症狀: 例数 }} & $\begin{array}{c}\text { 内向性群 } \\
129\end{array}$ & $\begin{array}{c}\text { 禹向性群 } \\
364 \text { 列 }\end{array}$ & $\begin{aligned} \text { 外向性群 } \\
231 \text { 例 }\end{aligned}$ & $\begin{array}{l}\text { 鈢 } \\
\text { 定 }\end{array}$ \\
\hline & & 例数(\%) & 例数(\%) & 例数(\%) & $x^{2}$ \\
\hline & 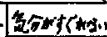 & $26(20.1)$ & $40(10.9)$ & $18(7.7)$ & $12.43^{n}$ \\
\hline (6) & 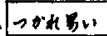 & $44(34.1)$ & $100(27.4)$ & $49(21.2)$ & $\eta .2 \hat{q}^{*}$ \\
\hline & monthat & $33(25.5)$ & $67(18.4)$ & $48(20.7)$ & 3.01 \\
\hline & 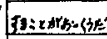 & $28(21.7)$ & $33(9,0)$ & $26(11.2)$ & $14,52^{*}$ \\
\hline & $\because 5+15 t_{3}$ & $20(15.5)$ & $22(6.0)$ & $8(3.4)$ & 19.57 \\
\hline 1 & 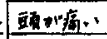 & $21(12.8)$ & $32(8.7)$ & $17(7.3)$ & $8.11^{7}$ \\
\hline & 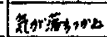 & $28(21.7)$ & $41(11,2)$ & $25(10.8)$ & $10.70^{* 1}$ \\
\hline ;it & 眼n13. & $12(9.3)$ & $16(4.3)$ & $9(3.8)$ & 5.73 \\
\hline \multirow[t]{3}{*}{ 毒 } & 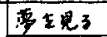 & $36(28.6)$ & $87(23.9)$ & $42(18.0)$ & $4.93^{4}$ \\
\hline & 汗加击易。 & $48(37.2)$ & $115(31.5)$ & $71(30,7)$ & 1.76 \\
\hline & Ansforits & $9(\quad 6.9)$ & $14(3.8)$ & $3(1.2)$ & $7.93^{4}$ \\
\hline 定 & 筮がんる & 01 & $6(1.6)$ & $2(0.8)$ & 2.51 \\
\hline \multirow[t]{4}{*}{ 症 } & 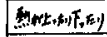 & $1(0.7)$ & $1(0.2)$ & $0(0)$ & 1,50 \\
\hline & 胸〔3いい” & $2(1.5)$ & $4(, .0)$ & 01 & \\
\hline & 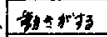 & $b(4.6)$ & $5(1.3)$ & $I(0.4)$ & $9.62^{*}$ \\
\hline & 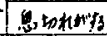 & $9(6.9)$ & $14(3.8)$ & $11(4.7)$ & 2.04 \\
\hline & 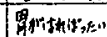 & $2(1.5)$ & $12(3.2)$ & $7(3.0)$ & 0.99 \\
\hline & 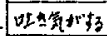 & $3(2.3)$ & $8(2.1)$ & $1(0.4)$ & 3.16 \\
\hline & 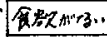 & $23(17.7)$ & $79(21.7)$ & $26(11.2)$ & $10.54^{7}$ \\
\hline & 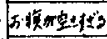 & $7(5.4)$ & $27(\eta, 4)$ & $11(4.7)$ & 1.97 \\
\hline & 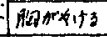 & $10(7.7)$ & $10(2,7)$ & $12(5.1)$ & $6.14^{*}$ \\
\hline & $1 \%, 3: m, 43$ & $12(9.3)$ & $14(3.8)$ & $10(4.3)$ & $8.40^{*}$ \\
\hline & 骨力虔川1 & $9(6.9)$ & $16(4.3)$ & $8(3.4)$ & 2.35 \\
\hline & 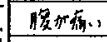 & $8(6.2)$ & $18(4.9)$ & $7(3.0)$ & 2.12 \\
\hline & 使通" & $9(6.9)$ & $21(5.7)$ & $11(4.7)$ & 0.78 \\
\hline \multirow[t]{2}{*}{ 采 } & 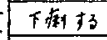 & $8(6.2)$ & $19(5.2)$ & $10(4,3)$ & 0.6 \\
\hline & 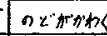 & $26(20.1)$ & $54(14.8)$ & $40(17.3)$ & 2.06 \\
\hline \multirow[t]{2}{*}{ 症 } & 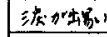 & $18(13.9)$ & $45(12.3)$ & $19(8.2)$ & 3.51 \\
\hline & 手是标: & $32(24.8)$ & $63(17.3)$ & $31(113.4)$ & $7.40^{*}$ \\
\hline & 体重和次 & $13 .(10.0)$ & $25(6.8)$ & $12(5.1)$ & 3.10 \\
\hline & 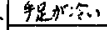 & 13 & 201 & $4.3)$ & 5.06 \\
\hline & & 1) & $13(3.5)$ & & 4.37 \\
\hline \multirow{2}{*}{ 内 } & 声A批了 & $11(8.5)$ & $20(5.4)$ & $9(3.8)$ & 3.46 \\
\hline & 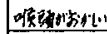 & $10(7.7)$ & $16(4.3)$ & $11(4.7)$ & 2.28 \\
\hline \multirow{2}{*}{ 反 } & 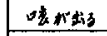 & $3(2.3)$ & $10(2.7)$ & $5(2.1)$ & \\
\hline & 胸䄱、=1 & $5(3.8)$ & $4(1.0)$ & $3(1.2)$ & $4.91^{\circ}$ \\
\hline \multirow{2}{*}{$\begin{array}{l}\text { 射 } \\
\text { 症 }\end{array}$} & 常加: & $27(20.9)$ & $41(11,2)$ & $31(13.4)$ & $\eta_{1} 6_{2}^{*}$ \\
\hline & 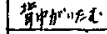 & $9(6.9)$ & $11(3.0)$ & $6(2.5)$ & $5,17^{*}$ \\
\hline \multirow{2}{*}{ 佛。 } & 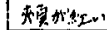 & $2(1.5)$ & $7(1.9)$ & $8(3.4)$ & 1.89 \\
\hline & 月结不犆 & $7(13.2)$ & $14(12.5)$ & $4(5.8)$ & 3.67 \\
\hline \multirow{4}{*}{$\begin{array}{l}\text { 病症 } \\
\text { 兼 } \\
\text { 尚渎 }\end{array}$} & 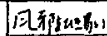 & $25(19.3)$ & $68(18.6)$ & $30(12.9)$ & 3.37 \\
\hline & 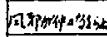 & $10(7.7)$ & $22(6.0)$ & $50(21.6)$ & $36.10^{*}$ \\
\hline & 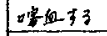 & $0(10)$ & $0(0)$ & $\circ 1$ & - \\
\hline & & .101 & 111 & 121 & 5.33 \\
\hline
\end{tabular}

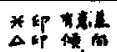

10.827, D. $\left.\chi^{2}=10.827\right)$ の多数を占めた。最後に C群では（表12（1）(2)), 同じく有意差ならびに 傾向をもつて症候の発現頻度の大なる項目はN 群 6, P群 8, D群11で，それぞれの対象（非N群 1 , 非 $\mathrm{P}$ 群 1 , 非 D群 0$)$ に比し有意 $\left(\mathrm{N} \cdot \chi^{2}=\right.$ 3. 841, P. $\chi^{2}=5.412, \mathrm{D} . \chi^{2}=10.827$ ）の多数を占め た。なお，以上の成績のそれぞれを $\mathrm{A} ・ \mathrm{~B} ・ \mathrm{C}$ 各群 别に比較すると $\mathrm{N} ・ \mathrm{P} ・ \mathrm{D} 3$ 群共, 有意差ならび 
表 8. 向性別にみた症候の現れ方 B群(不調者群)

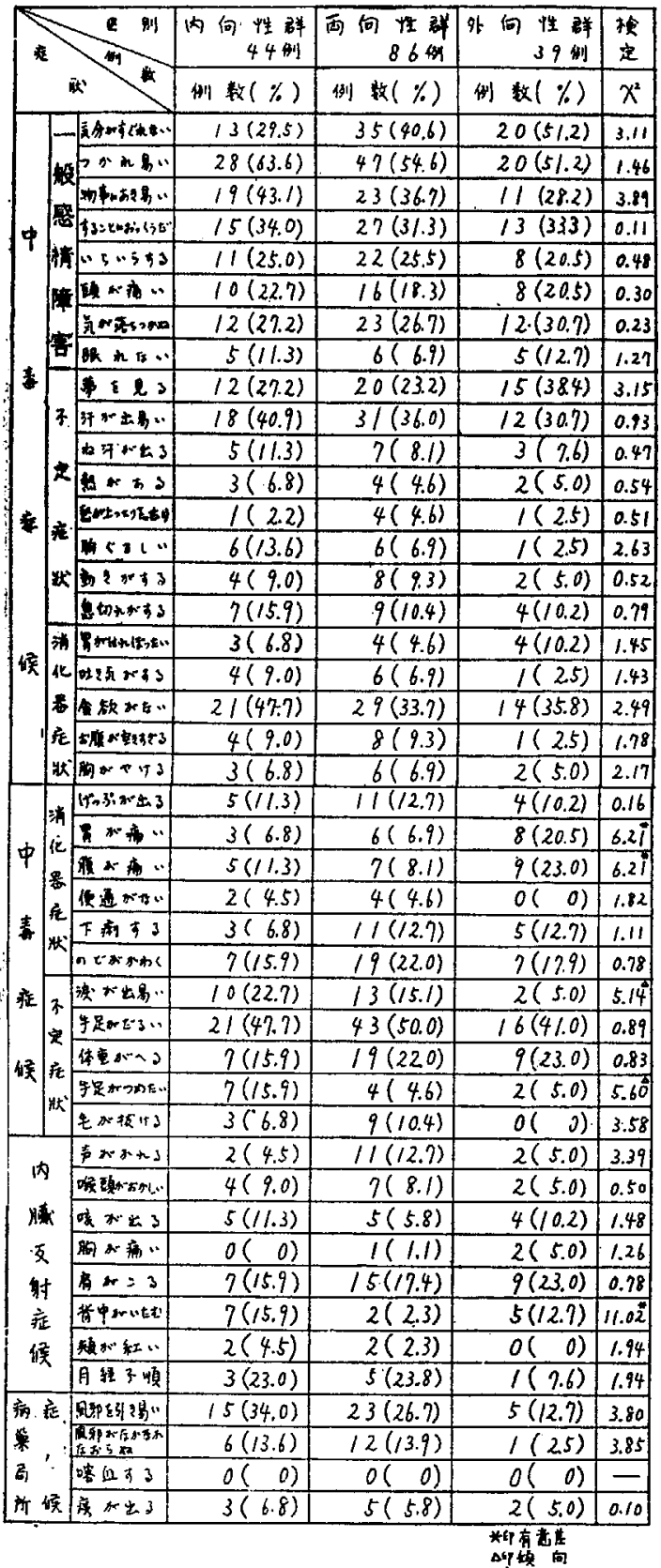

沉傾向をもつて, 症候の発現頻度の大なる項目が A群において他の 2 群に比し有意 $\left(\mathrm{N} \cdot \chi^{2}=13.815\right.$, P. $\chi^{2}=9.210, D \cdot \chi^{2}=9.210 ）$ の多数を占めてい た. 換言すれば，神経質傾向,固執傾向，抑椟傾向 の強いものは，それぞれの対象に比較して症候を 多く訴え，中でもA群において有意差をもつて， 他の 2 群に比し最も著明であることがわかつた。

以上を小括すると，（1）A群では，内向性
表 9、向性別にみた症候の現れ方 C 群（疾患群）

\begin{tabular}{|c|c|c|c|c|c|}
\hline \multirow{2}{*}{\multicolumn{2}{|c|}{ 症䘞数 }} & 叹向忹群 & $\begin{array}{c}\text { 禹向性群 } \\
47 \text { 工形 }\end{array}$ & $\begin{array}{r}\text { 外何恰群 } \\
28 \text { 例 }\end{array}$ & $\begin{array}{l}\text { 梗 } \\
\text { 定 }\end{array}$ \\
\hline & & 例数 (\%) & 例数 $(\%)$ & 例数( $(\%)$ & $x^{2}$ \\
\hline & 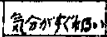 & $5(3 \mid .2)$ & $8(17.0)$ & $2(9.1)$ & $4.7^{6}$ \\
\hline & soin & $5(3 \mid, 2)$ & $20(42.5)$ & $5(17.8)$ & $4.83^{2}$ \\
\hline & 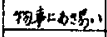 & $7(43.7)$ & 1112 & $.7)$ & 6.28 \\
\hline & 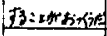 & $4(25.0)$ & $9(19.1)$ & $8(28.5)$ & 0.87 \\
\hline & $\because 5 n 5 j 3$ & $3(18.6)$ & $3(6.3)$ & $3(10.7)$ & 1.99 \\
\hline & 顽的象。 & $6(37.5)$ & $8(17.0)$ & $2(9.1)$ & $6.53^{*}$ \\
\hline & 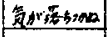 & +12 & $9(19.1)$ & $1(3.5)$ & 4.59 \\
\hline & 眼办 $13 n$ & $2(12.5)$ & 31 & & 1.17 \\
\hline & 厘垷3 & $2(12.5)$ & $6(12.7)$ & 612 & 1.15 \\
\hline 7 & 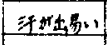 & $8(50.0)$ & $23(48.9)$ & $7(25.0)$ & 4.69 \\
\hline & 加汗が出? & $010)$ & $3(6.3)$ & $2(7.1)$ & 1.19 \\
\hline 定 & 算ans3 & Or & $0(10)$ & $0(0)$ & $=$ \\
\hline & 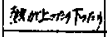 & 01 & 01 & 01 & - \\
\hline XXI & 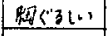 & $1(6.2)$ & $1(2.1)$ & $0 !$ & 1.53 \\
\hline 爿 & 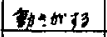 & $1(6.2)$ & $3(6.3)$ & $1(3.5)$ & 0.19 \\
\hline & 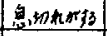 & 01 & $5(10.6)$ & $I(3.5)$ & 2.8 \\
\hline & 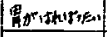 & $1(6.2)$ & $2(4.2)$ & $1(3.5)$ & 0.17 \\
\hline \multirow{5}{*}{ 候 } & $0 \pm=24+56$ & $|(6.2)|$ & $3(6.3)$ & $0 !$ & 1.79 \\
\hline & 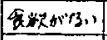 & $3(18.6)$ & $12(25.5)$ & $3(10.7)$ & 2.41 \\
\hline & 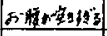 & $3(18.6)$ & $7(14.8)$ & $2(\eta .1)$ & 1.38 \\
\hline & 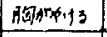 & $1(6.2)$ & $3(6.3)$ & $0(0)$ & 1.99 \\
\hline & 代, , 3; & $\mid \begin{array}{ll}16.2 \\
16\end{array}$ & $Q(\quad 0)$ & $2(7.1)$ & 3.11 \\
\hline \multirow[t]{2}{*}{ 中 } & 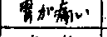 & $2(12.5)$ & $3(63)$ & $1(3,5)$ & 1.25 \\
\hline & 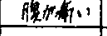 & 01 & $2 ! 4$ & & 2.04 \\
\hline \multirow[b]{2}{*}{18} & 使速加吅。 & $0<$ & $4(85)$ & $2(7.1)$ & $1 .+8$ \\
\hline & F满行 & 01 & 01 & $2(7.1)$ & 4.97 \\
\hline & 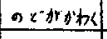 & $6(37.5)$ & $6(12.7)$ & $3(10.7)$ & $6.42^{2}$ \\
\hline & 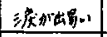 & $2(12.5)$ & $11(23.4)$ & $8(28.5)$ & 1.00 \\
\hline & 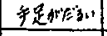 & $6(37.5)$ & $10(21.9)$ & $6(21.4)$ & 1.84 \\
\hline & 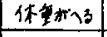 & $1(6.2)$ & $9:(9.1)$ & $(13.5)$ & $15.27^{7}$ \\
\hline & 铝机谓 & $1(6,2)$ & $11 \quad 2,1)$ & $3(10.7)$ & 2.63 \\
\hline & 毛标抵拉 & $0: 10)$ & $2(4,2)$ & $2(\pi .1)$ & $1 . .28$ \\
\hline \multirow{2}{*}{ 内 } & 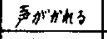 & 01 & $2(4,2)$ & 21 & 1.28 \\
\hline & 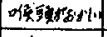 & $2(12.5)$ & $4(0.5)$ & $(3.5)$ & 1.32 \\
\hline \multirow{3}{*}{ 反 } & 嘈似, & $2(12.5)$ & $2(4,2)$ & $2(7.1)$ & 1.2 \\
\hline & 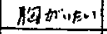 & $0\left(\begin{array}{ll}0 & 0\end{array}\right)$ & 01 & o) & - \\
\hline & 唇加: & $3(18.6)$ & $5(10.6)$ & $3(1 \cdot 9)$ & 0.8 \\
\hline \multirow{3}{*}{$\begin{array}{l}\text { 在 } \\
\text { 候 }\end{array}$} & 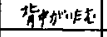 & $0(0)$ & $2(4.2)$ & $f(3,5)$ & 0.7 \\
\hline & 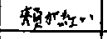 & 01 & $2(4,2)$ & $1(3,5)$ & 0.71 \\
\hline & 渱不不颔 & & $2(10.5)$ & $0(1 \quad 0)$ & 1.63 \\
\hline \multirow{4}{*}{$\begin{array}{l}\text { 症症 } \\
\text { 梁 } \\
\text { 所候 }\end{array}$} & 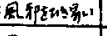 & $5(3 \mid, 2)$ & $\mid 1(23,4)$ & $7(25.0)$ & 0.55 \\
\hline & 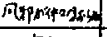 & $3(18.6)$ & $4(8,5)$ & $3(10.7)$ & 1.24 \\
\hline & 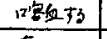 & $0(1$. & $0 .\left(\begin{array}{ll}1 & 0\end{array}\right)$ & $0(10)$ & - \\
\hline & 㽷地出了 & $1\left(\begin{array}{l}1 \\
0,2\end{array}\right)$ & $3 \cdot(6,3)$ & $3(10.7)$ & 0.4 \\
\hline
\end{tabular}

ならびに神経質，固執，抑楿楚傾向の強いものが, それぞれの対象に比し症候を多く訴える。（2） B群では，内・而・外 3 向性間に注症候の発現に ほとんど差なく，神経質，固執，抑禁傾问のもの はそれぞれの対象に比し症候の発現分比較的多加 つた。（3）C群ではB群とほとんど同じ関係に あつた。（4）A群，すなわち，健康者群が性格 
表10. 向性別 $(\mathrm{N} \cdot \mathrm{P} \cdot \mathrm{D}$ 群) にみた 症候の現れ方 $\mathrm{A}$ 群（健康者群）

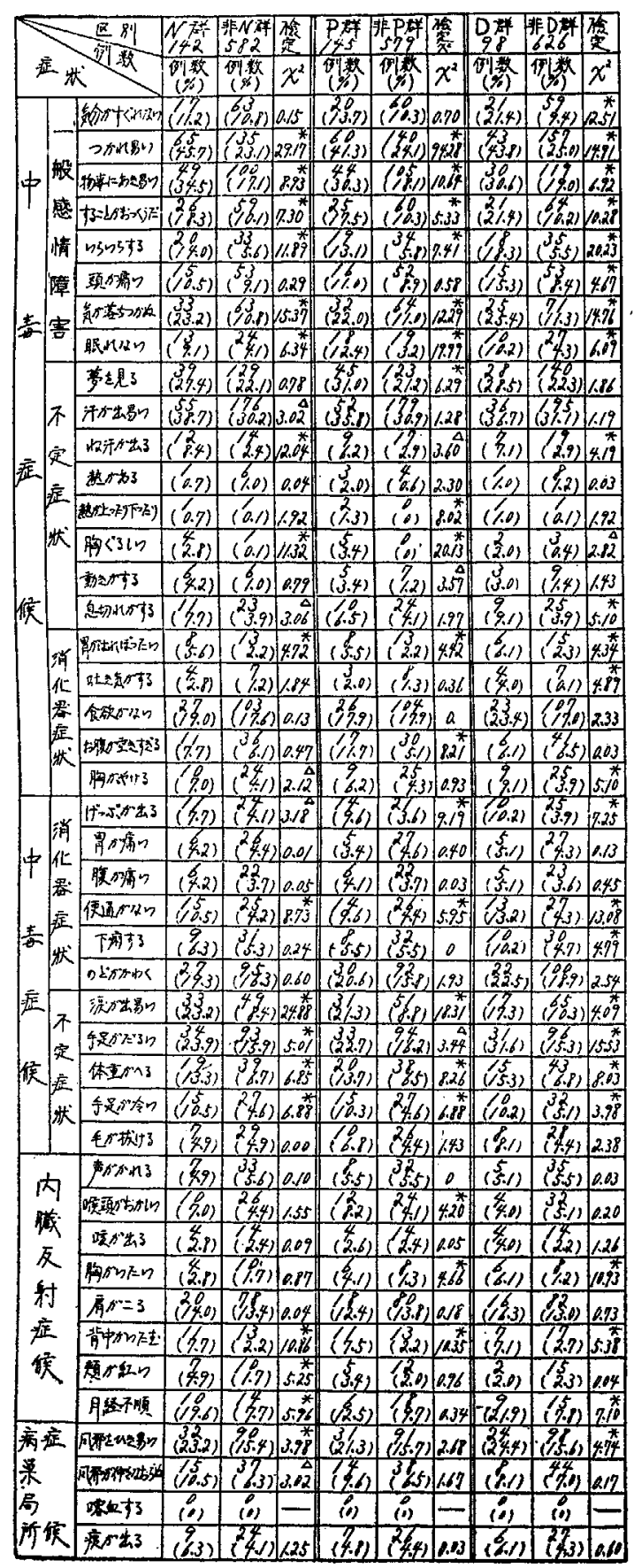

* 印 有意差, $\triangle$ 印傾向

傾向によつて著明に症候の発現が左右され，Bお よびC群（不調者群, 疾患群)ではA群に比し， 性格傾向によつて症候の発現が左右されること は，遥かに少なかつた。
表11. 向性別 $(\mathrm{N} \cdot \mathrm{P} \cdot \mathrm{D}$ 群) にみた 症候の現机方 B群（不調者群）

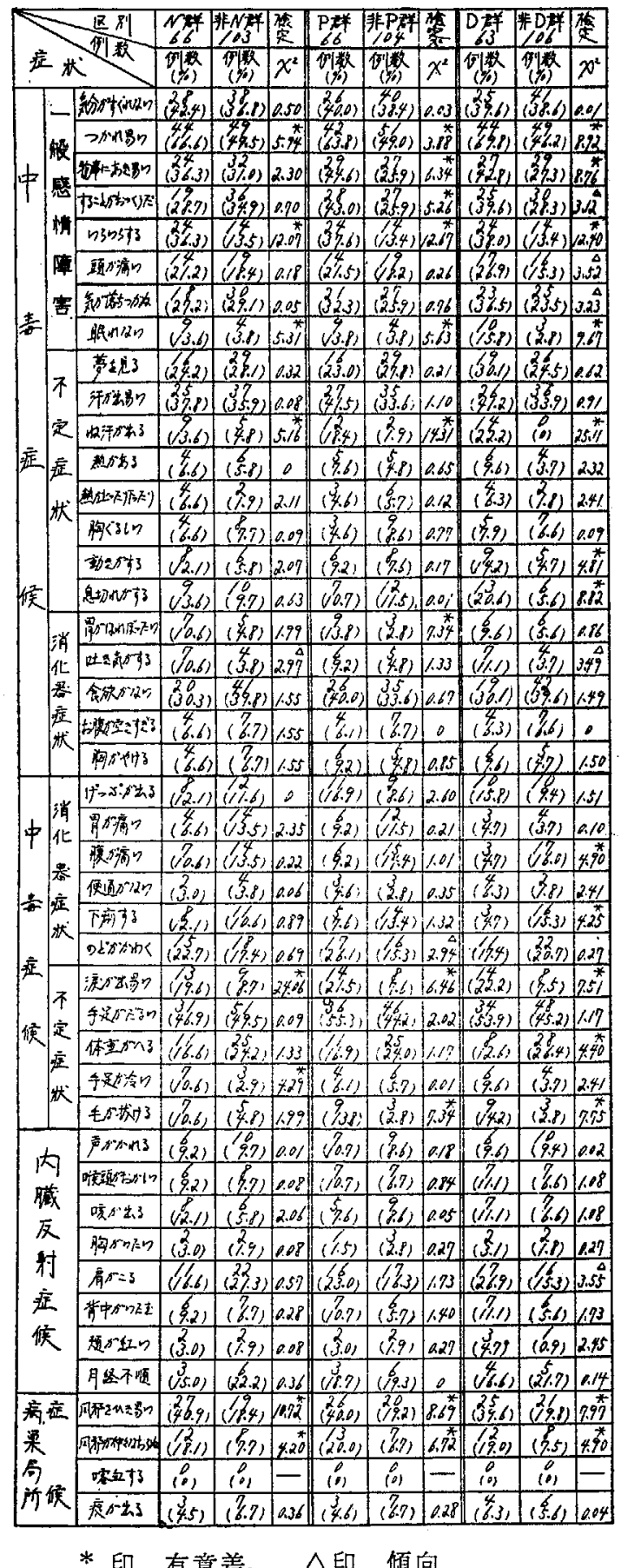

*印 有意羔， $\triangle$ 印傾向

（1）健康状態について

高校生の健康状態を調查して，72.5\%の大多数 が全く健康であると自ら考え，9.2\%に疾患を有 
表12. 激性別（N・D群）にみ心症

候の見机方 C 群 (疾患群)

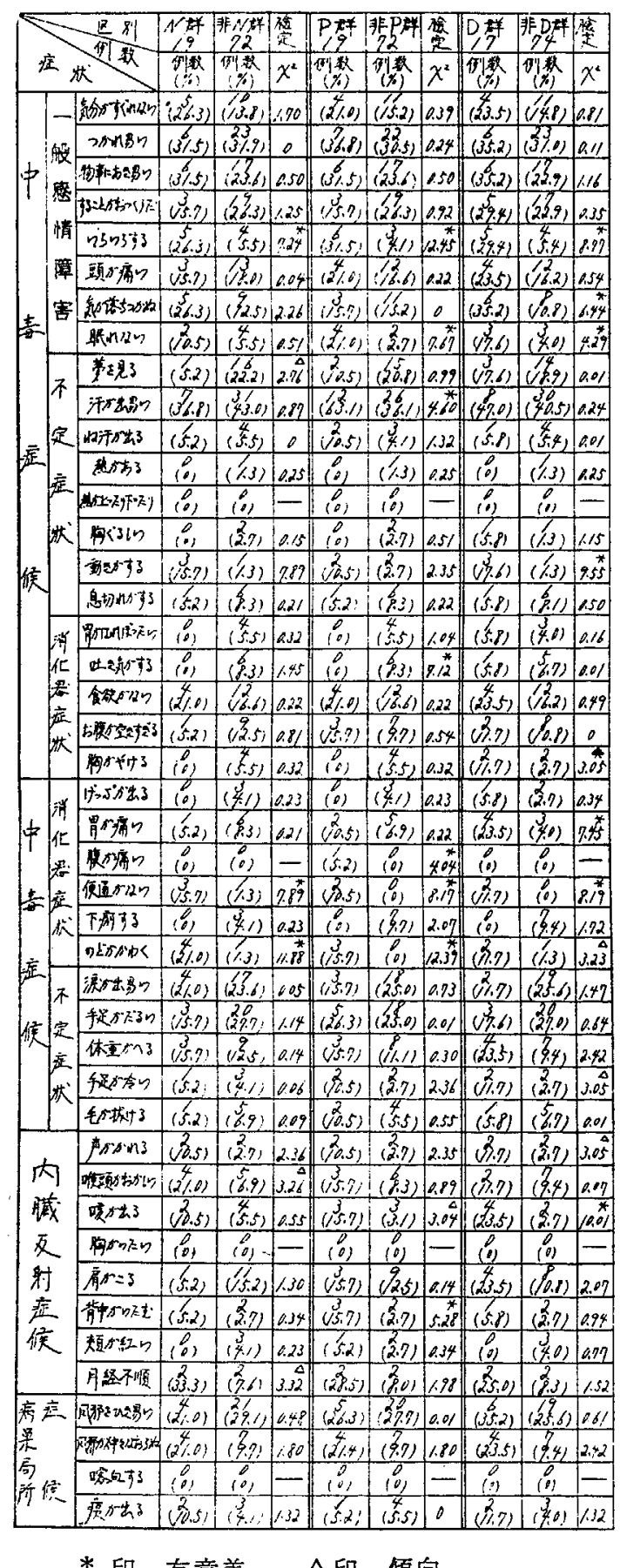

* 印 有意差, $\triangle$ 印 傾向

する者のある一方，17.1\%に身体の不調感を訴え るもの>あることは，夏季 7 月，梅雨期という調 查時期においては，気温，湿度などの身体に及は す影謷を十分に考虑しなければならないけれど
む,これらを単なる不調感として看過し去ること には危険が伴なうことであつて，このような subclinical な状態が，なんらかの疾急の発病準備 状態であるかも知れないということを考虑する必 要がある．このことは沖中氏症候群 ${ }^{6)}$ ，小金井氏 症候群 7$)$, 阿部教授らの脚気様状態 8$)$, 古閑の迷彩 結核9) 14)などの症候, 病因などに照し合せて, 一応考虑の余地のある問題として留意しなければ ならないということを本成績が示睃している。

（2）性格傾向について

性格傾向については，すでに，思春期より青年 に達するに従い，性格が，いわゆる内向性に傾く と言われているが，本研究に㧍いては身体状況を 一応保留してみると，19.2\%に内向性のものを観 て，その頻度は言われるごとく多くないことがわ かつた。これについては，内问性ということの判 定が検查に用いた Inventory Test の不備にあ るかも知れないということも，一応考虑しなけれ ばならないけれども, 季節, 身体状況, 環境など をも考慮して早急には断じ難いことが知られる。 一方, B群 (不調者群)において, 他の 2 群に比 し, 内向性, 神経質, 固執, 抑整傾向の多いこと は，この群に症候の発現の多いということ〉考え 合せてみると，興味深い成績を示していることが わかつた，上記のごとき性格傾向の者が身体不調 感を訴えるという psycho-somatic な観点から も，一方，身体が不調に陷つたがために，そのよ うな性格傾向を示すに至つたという somato-psychic な観点からも解釋されて，心身相関の問題 を解決するには，いかに多くの困難をともなうも のであるかということを知ることができた。

（3） $\mathbf{A} ・ \mathbf{B} \cdot \mathbf{C}$ 群別に観た症候の現われ方に วwて

本成績より，自ら健康であると考えているもの （A群二健康者群）の中にも，詳しくつきす〉ん で調查すれば，かなりの頻度に身体の異常を訴え ているもののいることがわかつたのであるが，中 でも多数を占めているのは一般感情障害であつ て，このことは，健康者であつても，われわれが 
日常経験するごとく, 生理的範囲内にあって, 種 々なる身心の異状を時に自覚するものであること を知るとともに, emotional な要因がいかに人間 の身心の理解にさいして重要であるかを示唆して いる、また，B群 (不調者群)においては，A群 に比し多くの症状が訴えられたということは， 当然なことではあるが，それに比しC群の症状発 現頻度の少なかつたことは，その疾患が，一般に 軽症のもの，および，身体の一部に限局している 結膜炎, トラコーマ, 㐭炎なぼが多かつたためと 解釋される。もし，C群として内科的疾患，こと に中・重症例を対象とすれば，さらに異なつた成 績が期待されよう。

（4）向性別にみた症候の現われ方について

特殊の性格傾向者について，その愁訴，症候の 発現の最も多いのは健康者群であり, 不調者群, 疾患群においては性格傾向によつて，さほど，症 候の発現が左右されないことを知つた。すなわ ち, 健康者群では, その性格傾向が, 内向性, 神 経質，固執，抑栕傾向の強いものほと，ささいな 身心の変調に注意を向け, それに執着し, 心気性 となり,その結果, 愁訴が多く現われることが理 解される。一方, 不調者群では, 現実では, 症候 の発現が多いにも拘らず，その性格傾向の差異に よつて，予想したはどに症候発現率が左右されな いことがわかつたが，この事実は次の二つのこと が結びついて生じた現象と，一応の解釋ができよ う. その一つは健康者群の症候発現のメカニズム と同様に, 内向性, 神経質, 固執, 抑䇾傾向の強いも のが身心の不調に気づき,健康者群よりも,さらに 多くの症候を自覚してくる場合であつて, 性格傾 向の質と量の問題によって一芯解され，他の一つ は, 性格傾向方, 内向性, 神経質, 固執, 抑曁傾向 でもないものが，なんらかの疾患を潜在させてお り，そのために，性格傾向の如何に拘らず，多く の症候を訴えるに至るであろうことが窺われるの である。この両者が混在してB群を形成し, 症候 の発現頻度が性格傾向に関係なく平均して現われ てくるものであろうと解される。したがつて，実
際の臨床においては，外向性者，または，神経 質，固執，抑梪傾向でないものが症候を多く訴え た場合に，その潜在疾㭧，または，未発見の病巣 についてより多くの注意を向ける必要がある。

疾患群でも, 不調者群と同様, さほど, 性格傾 向によつて症候の発現が影響されていないのは, その有する疾患が軽症で, 身体の一部に限局され たものが多かつたこと〉，一度，すでに疾患に羅 患したということが，却って，自分の不調不振の 原因の不明の場合よりも，患者の心理を安定した 状態に落着加せ，性格傾向如何に拘らす，此較的 限定された症候のみを訴えるに至るものであろう

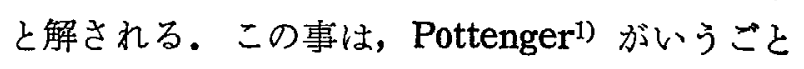
く, 結核病変のいまだ明らかでない時期に，不定 の症状を多く訴え, 病変が明瞭となり, 疾患を正 しく認識した時に，前記の不定の症候が消失して 臟器固有の症状のみが現われてくるということ〉 照し合せてみても納得されよう。

\section{結 論}

以上われわれの得たる成績を綜合して次の結 論に到達した。

（1）自ら健康であると考えている者（健康者 群）の中にも,さらに詳細に調査すれば, 季節, 環境などにより，種々なる不定の症状を訴えるも の১あることを知つた，さらに，性格傾向が内向 性, 神経質, 固執, 抑枚傾向にあるものほど, 挀 える症候が多いことがわかつた。

（2）身体が不調であると考えている者（不調 者群）には，その性格傾向が，内向性，神経質， 固執，抑禁傾向の強いものが，他の 2 群（健康者， 群及び疾患群）よりも多かつた。また，症候の発 現も 3 群中最も高率であつた。しかし, 症候の発 現は，さ注ど，性格傾向には影響されない。この ことは, 一応, 内尚性格者が, いわゆる疾病をつ くるとなす psycho-somatic の概念を裹つけるこ とつなり，また，この群の中における，両向性， 外向性者などにおいては, 明らかに，なんらかの 疾患が潜在しているのではないかという示唆がみ られるのである. 
（3）疾患群では，不調者群と同倳，その症候 の発現頻度は，その有卞る性格傾向に影響される ことが少ない。このことは，疾患に霍患したとい う事契の前に，心理状態に沙いて，ある安定感を もたらし，性格傾向に関係なく，固有の症状のみ 分挀えられるためであるうと考えられた。

\section{引用文献}

1) Pottenger: Tuberculosis, 1953. -2) 古閑: 第 14 回日本心理学会大会抄録，S，24，一集）淡 路：向性調查と向性指数，心理学研究， 7, 1932. 一4) 矢田部: 京都大学文学部研究䄫要第 $3, S, 29$. Guiford, J.P. \& Martin, H.G.: The GuifordMartin, Personnel Inventry Test. California 1943. - 5) Taylor, J.A.: J. Abnorm. and Soci- alpsycho. 482, 1953. 一6) 冲中：治瞭, Vol. 33, No. 11. -7) 小金井：臨内小, Vol. 8, No. 3. 8）阿部：日内会誌, Vol. 44 , No. 11, S. 31. - -9) 古閉: 結核研究の進歩, Vol. 19, S. 32. - 10) 古 閑：東京憼恵医大誌，Vol. 67, No. 4. - 11) 古䦥 他：臨内小，Vol. 9, No. 4. - 12) 古䦙他: 臨内 小, Vol, 9, No. 6. - 13) 古閑他: 臨内小, Vol. 10, No. 5, - 14) 桶口: 東京慈恵医大誌, Vol. 70 , No. 4.

\section{考支献}

1）鈴木：肺結核患者の精神病理化関する研究。一 2）長山: 短正医学, Vol, 6, S.32, -3) 長山: 東京慈惠医大誌，Vol. 74, No. 7. 一4) 高良: 東 京慈恵医大誌, Vol. 74, No. 6. - 5) K. Koga: Jikei Medical Journal, Vol. 3, No. 2. -6) Anton J. Carlson: Feeling and Emotions, 1950. 